\title{
Rational Explanation of the Relationship between the Material Intellect and the Active Intellect from the Perspective of Averroes
}

\author{
DAVOUD ZANDI ${ }^{1}$
}

\begin{abstract}
The relationship between the material intellect and the active intellect from Averroes' perspective is an important and yet complicated part of his philosophy. His views on these issues are ambiguous since they are derived from the Aristotle's theories which seem obscure in this regard. The aim of the present study is to discover Averroes' final theory on the relationship between the material intellect and the active intellect and their connection to human soul. Reviewing various theories of Averroes on this issue, this study shows that despite ambiguity in his explanations, his final theory is that he believes these two intellects exist apart from human soul. Considering the relationship between the material intellect and the active intellect, he believes that in some aspects both of them are the same, yet they are different in some other aspects that is, regarding their acts, they are different because the active intellect acts as a creator of forms while the material intellect is just a receiver of the forms. Nevertheless, they are the same, since the material intellect achieves perfection through the active intellect.
\end{abstract}

Keywords: active intellect, Aristotle, Averroes, material intellect, soul

Intellection from the perspective of Averroes is an important and yet controversial field of his thought. In this respect he follows the Aristotelian tradition. But sometimes, the intellectual system in which he was grown up, led him to the perversion from Aristotelian thought. Averroes' views on intellect can be sought in the two most influential of his works namely Talkhis Kitab al-Nafs (Middle Commentary on De Anima) and al-Sharh al-Kabir li Kitab al-Nafs li Arastu (Long Commentary on De Anima). In his book entitled al-Sharh al-Kabir li Kitab al-Nafs li Arastu (Long Commentary on De Anima) Averroes gives brief and somewhat ambiguous and detailed explanations on the nature of the active and the material intellect.

The fundamental question here is that how is the relationship between the material intellect and the active intellect and how these two are related to human soul? In other words, Is intellect inherent in human soul or is it out of the soul? Since Averroes' position on these subjects is ambiguous so answering these questions might not be easy. Averroes' position on these issues is ambiguous. Since his views on this issue are derived from the Aristotle's theories, this ambiguity comes from the intricacies in Aristotle's opinion in this regard. In his books Metaphysics, The History of Animals and On the Soul, Aristotle has presented his views on this respect. Aristotle's controversial remarks about intellect are due to his different approaches to the intellect in his writings. In his books entitled The History of Animals, Metaphysics, Physics, On Generation and Corruption and Nicomachean Ethics Aristotle ultimately, explores intellect with different new approaches and characteristic. "There is no certain aspect of his philosophy, more

\footnotetext{
${ }^{1}$ Davoud Zandi, Ph.D., Assistant Professor at Department of Islamic Philosophy, Islamic Azad University, Hamedan Branch, HAMEDAN, Iran, email: davodzandi@gmail.com.
} 
controversial than his attitude toward intellect" (Gallop 1999). For example, some traits which previously were absolutely attributed to Intellect now he attributes them to the active Intellect (Aristotle 1999). In the same section Aristotle poses newer features which he did not previously mentioned (Aristotle 1999). One of these features is that this intellect always thinks. Another trait which in Aristotle's view is exclusively attributed to the active intellect is immortality of this kind of intellect.

\section{Relationship between Intellect and Human Soul}

In his book entitled al-Sharh al-Kabir li Kitab al-Nafs li Arastu (Long Commentary on De Anima), Averroes in some cases deems the active intellect and the material intellect as eternal substance which independently exist out of human soul. In some other cases, he considers these two intellects, as two parts of human soul. Although there are differences in his division of intellect, his final opinion on this subject is that he believes in the separation of the active intellect from human soul. Examples of these different theories are as follows:

It is therefore essential to mention that a part of the soul which is called intellect has three different and distinguished parts; the first part is the receiver of all forms, the second one turns the material intellect (al-'Aql al-Hawlani) into the actual intellect (al-'Aql bi al-Fi'l), and the third one develops the potential intelligible into the actual intelligible (Averroes 2001).

Elsewhere he says:

It is clear from the words of Aristotle that he believed in two different intellects in human soul.one is the potential intellect and the other is the active intellect which actualizes the forms received in the potential intellect. These two intellects are immortal and eternal. The active intellect (al-'Aql al-Fa'al) compared to the material intellect, is like a form for matter (Averroes 2001).

On the other hand Averroes presents a tripartite division on intellect as he says:

We should believe that there are three parts of Intellect in human soul, one of which is the receptive intellect (al-Aql al-Qabil) and the second is the active intellect is the second and the third is the phenomenal one (i.e. the effect of the active intellect on the receptive intellect). Two of these three are eternal intellect and the third is somehow mortal and somehow is eternal (Averroes 2001).

Considering the relationship of the material intellect with the active intellect, $\mathrm{He}$ believes that in some aspects both of them are the same yet they are different in some other aspects. Regarding their acts they are different because the act of the active intellect is creation but the material intellect acts as a receiver of the forms. Nevertheless, they are the same, since the material intellect achieves perfection through the active intellect. On the other hand, he says: "The external intellect which is connected to us has two faculties; the active and the material intellect" (Averroes 2001). Here it is evident that from Averroes' perspective intellect is inherently and practically independent from the body and is located beyond the human soul. This includes both the active and the material intellect. 
Vol. 8: (Dec.) 2015

Considering the different functions of both the active and the material intellect, Averroes deems both of them as the two aspects of one single intellect. Sometimes he mentions the separation of them from the soul and sometimes presents them as faculties which exist in the soul as non-material beings (Averroes 2001). Following Aristotle's theory, Averroes likens the function of the active intellect to light. As the light actualizes the potential colours and prepares them to be seen. Also the active intellect actualizes the potential intelligible (Averroes 2001).

\section{Relationship between the Active and the Material Intellect}

Then Averroes deals with the important subject of relationship between the material intellect and the active intellect. In this regard, he says: the relationship of the active intellect with the material intellect is like the relationship of light with a transparent object. As light is the perfection of physical objects; the active intellect is the perfection of material intellect as well. The material intellect perceives intelligible to the extent that are made perfect and clear by the active intellect. Therefore the active intellect actualizes the potential concepts; in a way that the material intellect can perceive them. So is the relationship of the material intellect with the active intellect (Averroes 2001).

Following Aristotle, Averroes after expressing the relationship between the material and active intellect distinguishes the active intellect from the material intellect. The active intellect is pure actuality and actualizes all concepts and forms while none of these features exist in the material intellect (Hasan Fathi 2012). Averroes believes in the strong connection between the active and the material intellect and believes that, as the passive intellect can be actualized through the active intellect, the active intellect also through actualizing the material intellect is manifested in the universe. He believes that the active intellect and theoretical thinking of human being intersect at a common place in the passive intellect and the active intellect through theoretical intelligible makes connection with us (Averroes 2001). Thus the active intellect in Averroes' perspective in some aspects is separated from the material intellect and yet in some other aspects is connected to it.

After expressing the relationship between the active intellect and the material intellect, he says: "eternity and immortality is just for human species, immortality exists but there is no individual immortality", he argues that Aristotle's definition of the soul indicates not all parts of the soul but some part of it, is connected to body. For some reasons, Averroes believes in unity of immortal soul or intellect. The Main reason is that considering the diversity of souls, leads to an infinite number of actual existent which is impossible (Averroes 2006). Immateriality of the active intellect and its divine nature are principles which he has tried to prove in his book entitled al-Sharh al-Kabir li Kitab al-Nafs li Arastu (Long Commentary on De Anima).

\section{Assessment of Averroes' Perspective}

Following Aristotle, Averroes believes that the active intellect has attributes such as being immaterial, non-passive and ever thoughtful. In his opinion the active intellect is a divine and metaphysical being which exists apart from human soul. This divine nature of the active intellect is due to its eternity and immortality. In his thought the active sometimes is considered apart from the material intellect and sometimes is deemed in connection with it. But his overall interpretation implies the separation of the active intellect from the human soul and its unity.

The problem which has raised so many different commentaries in this respect is that if Averroes' words be seen from religious perspective, it can be said that the unity of the active intellect in his thought does not lead to questioning the immortality of individual souls and the punishment and reward in the hereafter because Averroes had a special respect for 
resurrection and believed in it. In his opinion following the Prophets and believing in resurrection entails numerous educational impacts and it is necessary for the perfecting of moral virtues (Averroes 2006). Thus, Averroes accepts plurality of souls and intellects of mankind in the realm of religion and yet believes in the unity of them in the philosophical realm.

His interpretations especially in his book entitled al-Sharh al-Kabir li Kitab al-Nafs li Arastu (Long Commentary on De Anima) is in contrast to Tahafut at Tahafut (Incoherence of the Incoherence) implies individual immortality (Averroes 1961). Here, in agreement with Etienne Gilson we can say that 'Averroes was never separated from Islamic teachings. He accepted the reality of prophecy and placed prophets on the summit of human knowledge since religion and philosophy comply with each other' (Gilson 1980).

The aim of this study was to discover Averroes' final views on the relationship between the active and the material intellect, and their relationship with human soul. It is worth mentioning that Averroes' opinions on these issues are ambiguous since they are derived from the Aristotle's theories which are obscure in this regard. Exploring his different views on this subject, we can conclude that Averroes' final theory is that he believes in the separation of these two intellects from human soul. Considering the relationship between the material intellect and the active intellect, He believes that in some aspects both of them are the same yet they are different in some other aspects, namely regarding their acts they are different because the active intellect acts as creator of forms while the material intellect is just receiver of the forms. Nevertheless, they are the same, since the material intellect achieves perfection through the active intellect. In other words, from Averroes' perspective there is a strong connection between the active and the material intellect since the material intellect can be actualized through the active intellect, the active intellect also through actualizing the material intellect is manifested in the universe. Also he believes that the active intellect and theoretical thinking of human being intersect at a common place in the material intellect and the active intellect through theoretical intelligible makes connection with human soul.

\section{References}

Aristotle. 1999. On the Soul. Edited by A. M. Davoudi. Tehran: Hikmat Publications. Averroes. 1961. Fasl al-Maqal wa-Taqrir ma bayn al-Shari'ah wal al-Hikmah min al-Ittisal. Edited by A. N. Nadir. Beirut: al-Maktabah al-Kathulikiyah.

Averroes. 2001. Al-Sharh al-Kabir li Kitab al-Nafs li Arastu (Long Commentary on De Anima). Edited by I. al-Gharbi. Tunis: Bayt al-Hikma.

Averroes. 2006. Tahafut al-Tahafut (The Incoherence of the Incoherence). Edited by M. Aribi. Beirut: Dar al-Fikr al-Lubnani.

Gallop, D. 1999. The Routledge History of Philosophy. Vol. 2. Kentucky: Routledge.

Gilson, É. 1980. History of Christian Philosophy in the Middle Ages. London: Sheed \& Ward.

Hasan Fathi, K. 2012. Active intellect's place in Aristotle's thought and it's impacts on interpretation of Yuhanna Nahwi and Averroes. History of Philosophy. 